\title{
Kajian Penanggulangan Gizi Balita Pasca Bencana Gempa Bumi Di Desa Dasan Geria Kabupaten Lombok Barat
}

\author{
Febrina Sulistiawati ${ }^{1}$, Taufiqqurrahman ${ }^{2}$ \\ ${ }^{1,2}$ Universitas Nahdlatul Ulama Nusa Tenggara Barat \\ Email :r_febri@yahoo.co.id
}

\begin{abstract}
Abstrak : Wilayah Pulau Lombok yang terletak di Provinsi Nusa Tengara Barat mengalami goncangan gempa 6,4 SR pada tanggal 29 Juli 2018. Dari 5 kabupaten/kota yang ada di Pulau Lombok, kerusakan terbesar dialami oleh masyarakat di Kabupaten Lombok Timur. Kerusakan tersebut ditambah dengan gempa susulan 7.0 SR pada tanggal 5 Agustus 2018. Gempa kembali menghantam masyarakat wilayah Lombok namun kerusakan terbesar dialami oleh masyarakat di Kabupaten Lombok Utara. Masyarakat di Kabupaten Lombok Barat, Kabupaten Lombok Tengah dan Kota Mataram pun terkena dampaknya. Gempa 6,2 SR selanjutnya menghantam kembali pada tanggal 9 Agustus 2018. Serangkaian goncangan tersebut merupakan goncangan yang berat bagi warga terdampak karena tidak hanya korban jiwa, bencana gempa seringkali mengakibatkan banyak korban luka-luka, mengungsi, serta merusak bangunan rumah dan fasilitas umum termasuk fasilisitas ibadah, perkantoran, jalan dan pelayanan kesehatan. Masalah yang sering kali luput dari perhatian ialah kecukupan gizi bagi penyintas bencana. Penurunan status gizi pasca bencana dapat terjadi akibat layanan kesehatan terbatas, terputusnya jalur distribusi makanan serta sanitasi yang buruk (Kementrian Kesehatan RI, 2012). Kebutuhan layanan kesehatan dan pangan jelas akan meningkat pada daerah pasca bencana. Untuk itu manajemen penanggulangan untuk pemenuhan status gizi penyintas bencana perlu menjadi perhatian semua pihak terutama kebutuhan nutrisi bayi, balita, anak-anak, ibu hamil serta lansia yang rentan terserang penyakit pasca bencana (Tumenggung, 2017).Penelitian ini bertujuan untuk mengkaji efektifitas penanggulangan gizi balita pasca bencana gempa bumi di Desa Dasan Geria Kecamatan Lingsar Kabupaten Lombok Barat. Desain penelitian ini menggunakan pendekatan kualitatif, dimana peneliti sebagai instrumen kunci. Teknik pengumpulan data dilakukan secara triangulasi (gabungan). Metode pengumpulan data yang digunakan adalah wawancara mendalam, observasi dan studi dokumen pada 10 orang informan utama dan 10 orang informan pendukung. Análisis data bersifat induktif/kualitatif dan hasil penelitian lebih menekankan makna daripada generalisasi. Hasil penelitian menunjukkan bahwa kegiatan gizi pra bencana belum terlaksana dengan baik karena belum adanya data awal wilayah yang rawan terkena gempa serta belum terlaksananya sosialisasi dan pelatihan petugas untuk penanganan gizi balita. Demikian pula dengan ketersediaan makanan untuk balita baik dari segi jenis, kuantitas maupun kualitas belum memenuhi standar Angka Kecukupan Gizi yang dianjurkan. Sementara itu, kegiatan gizi pasca bencana berupa pemantauan dan evaluasi telah dilaksanakan dengan tujuan untuk meningkatkan dan mempertahankan status gizi dan kesehatan balita korban bencana
\end{abstract}

Kata kunci : Penanggulangan Gizi Balita, Bencana Gempa Bumi, Desa Dasan Geria

\section{PENDAHULUAN}

Wilayah Indonesia berada di jalur gempa teraktif di dunia karena dikelilingi oleh Cincin Api Pasifik (ring of fire) dan berada di atas tiga tumbukan lempeng benua, yakni Indo-Australia dari sebelah selatan, Eurasia dari utara, dan Pasifik dari timur. Kondisi geografis ini di satu sisi menjadikan Indonesia sebagai wilayah yang rawan bencana letusan gunung api, gempa, dan tsunami namun di sisi lain menjadikan Indonesia sebagai wilayah subur dan kaya secara hayati.

Bencana merupakan kejadian luar biasa yang terjadi diluar kendali manusia, tanpa diketahui waktu terjadinya dan seberapa besar dampak kerugian yang akan ditimbulkan. Dampak bencana dapat berupa rusaknya lingkungan dan menyebabkan 
kematian masal. Besarnya dampak tersebut membuat pentingnya perhatian seluruh masyarakat untuk kesiapsiagaan dalam menghadapi bencana (Sinaga, 2015). Selain itu, julukan sebagai negara dengan laboratorium bencana sudah melekat bahkan tidak asing lagi terdengar untuk negara Indonesia mengingat Indonesia merupakan salah satu negara yang sangat rawan dengan bencana alam. Potensi bencana tersebut yaitu gempa bumi, tsunami, banjir, tanah longsor, kekeringan, kebakaran hutan dan lahan, gunung api, dan masih banyak lagi (Oktari, 2019). Secara fisik bencana-bencana tersebut tentu berdampak pada rusaknya saran dan prasarana, pemukiman, juga fasilitas umum lainnya termasuk fasilitas kesehatan. Hal ini membuka peluang munculnya bencana baru seperti KLB penyakit tertentu.

Serangkaian gempa bumi yang melanda Pulau Lombok sejak bulan Juli 2018 menyebabkan banyaknya korban jiwa, merusak bangunan rumah dan fasilitas umum termasuk fasilisitas ibadah, perkantoran, jalan dan pelayanan kesehatan. Masalah yang sering kali luput dari perhatian ialah kecukupan gizi bagi penyintas bencana. Penurunan status gizi pasca bencana dapat terjadi akibat layanan kesehatan terbatas, terputusnya jalur distribusi makanan serta sanitasi yang buruk (Kementrian Kesehatan RI, 2012). Kebutuhan layanan kesehatan dan pangan jelas akan meningkat pada daerah pasca bencana. Untuk itu manajemen penanggulangan untuk pemenuhan status gizi penyintas bencana perlu menjadi perhatian semua pihak terutama kebutuhan nutrisi bayi, balita, anak-anak, ibu hamil serta lansia yang rentan terserang penyakit pasca bencana (Tumenggung, 2017).

Masalah yang timbul pada bayi dan balita dapat berupa kurang gizi, diantaranya karena tidak tercukupinya air susu ibu (ASI) dan makanan pendamping ASI (MP-ASI) akibat terpisah dari ibunya. Selain itu, semakin memburuknya status gizi kelompok masyarakat, bantuan makanan yang sering terlambat, tidak berkesinambungan dan terbatasnya ketersediaan pangan lokal memperburuk kondisi yang ada. Masalah tersebut diperburuk lagi dengan kurangnya pengetahuan dalam penyiapan makanan buatan lokal khususnya untuk bayi dan balita. Bayi dan anak berumur bawah dua tahun (baduta) merupakan kelompok yang paling rentan dan memerlukan penanganan gizi khusus. Pemberian makanan yang tidak tepat pada kelompok tersebut dapat meningkatkan resiko kesakitan dan kematian terlebih pada situasi bencana (Haniarti dan Yusuf, 2020). Penelitian ini bertujuan untuk mengkaji efektifitas penanggulangan gizi balita pasca bencana gempa bumi di Desa Dasan Geria Kecamatan Lingsar Kabupaten Lombok Barat.

\section{METODE PENELITIAN}

\section{A. Jenis Penelitian}

Desain penelitian ini menggunakan pendekatan kualitatif, dimana peneliti sebagai instrumen kunci. Teknik pengumpulan data dilakukan secara triangulasi (gabungan). Metode pengumpulan data yang digunakan adalah wawancara mendalam, observasi dan studi dokumen. Análisis data bersifat induktif/kualitatif dan hasil penelitian lebih menekankan makna daripada generalisasi

\section{B. Informan penelitian}

Informan dalam penelitian ini dibagi dua, yaitu :

1. Informan utama

Informan utama merupakan subjek utama dalam penelitian ini, yaitu 10 orang ibu yang memiliki balita yang terkena dampak gempa bumi di Desa Dasan Geria Kecamatan Lingsar Kabupaten Lombok Barat.

2. Informan pendukung

Informan pendukung dalam penelitian ini adalah pihak stakeholder yang secara langsung terlibat dalam penanggulangan gizi balita yang terkena dampak gempa bumi sebanyak 10 orang.

\section{Instrumen Penelitian}

Instrumen yang digunakan dalam penelitian ini meliputi :

1. Pedoman wawancara mendalam

2. Pedoman observasi

3. Alat perekam

4. Buku catatan

5. Alat tulis 


\section{Pengumpulan Data}

Metode kualitatif akan menggunakan data yang diambil melalui wawancara, observasi lapangan, atau dokumen yang ada (Raco, 2010). Pengumpulan data pada penelitian ini dilakukan dengan latar tertutup dimana hubungan peneliti dengan informan perlu akrab dengan menjamin kerahasiaan informan yang diwawancarai. Teknik pengumpulan data dalam penelitian ini menggunakan beberapa teknik yaitu wawancara mendalam, observasi, dan studi dokumen.

1. Wawancara mendalam

Wawancara mendalam dilakukan peneliti dengan melakukan tanya jawab dengan informan secara langsung menggunakan pedoman wawancara yang telah disusun oleh peneliti.

2. Observasi

Observasi adalah suatu penyelidikan yang dijalankan secara sistematis dan sengaja diadakan dengan menggunakan alat indera terutama mata terhadap kejadian-kejadian yang langsung.

3. Studi dokumen

Metode ini dilaksanakan untuk memperoleh data yang berkaitan dengan permasalahan penelitian melalui laporan, buku, dan dokumen lain yang berhubungan dengan penanggulangan gizi balita pasca bencana gempa.

\section{E. Analisis Data}

Penelitian ini menggunakan analisis data kualitatif yang dikembangkan atau lebih dikenal dengan analisis interaktif (interactive model of analysis). Analisis ini terdiri dari 3 (tiga) komponen utama yaitu reduksi data, penyajian data dan penarikan kesimpulan yang dilakukan dalam bentuk interaktif dengan proses pengumpulan data sebagai suatu siklus (Milles dan Hubberman, 1992).

Tiga komponen tersebut adalah :

1. Reduksi data

Merupakan proses pemilihan, pemusatan perhatian pada penyederhanaan, pengabstraksian dan transformasi data kasar yang muncul dari catatan tertulis di lapangan dengan memfokuskan data yang relevan melalui pemisahan data, mempertegas data, membuang hal yang tidak pentingdan mengatur data sedemikian rupa sehingga kesimpulan akhir dapat dilaksanakan.

2. Penyajian data

Merupakan suatu kegiatan dengan adanya penyajian bagi data kualitatif dalam bentuk kolom, tabel maupun deskripsi. Susunan penyajian data yang baik dan jelas sistematikanya sangatlah diperlukan untuk melangkah pada tahapan penelitian kualitatif selanjutnya.

3. Penarikan kesimpulan

Penarikan kesimpulan dapat dilakukan berdasarkan hasil penelitian dengan memperhatikan hasil wawancara, observasi dan studi dokumen (berupa data-data awal yang belum siap digunakan dalam kajian), setelah data tersebut direduksi dan disajikan.

\section{HASIL DAN PEMBAHASAN}

Dalam penanggulangan bencana, kegiatan gizi merupakan rangkaian kegiatan yang dimulai sejak pra bencana, pada situasi bencana (tanggap darurat awal dan tanggap darurat lanjut) serta pasca bencana. Kelompok yang paling rentan dan memerlukan penanganan gizi khusus adalah bayi dan anak berumur di bawah dua tahun (baduta). Pemberian makanan yang tidak tepat pada kelompok tersebut dapat meningkatkan risiko kesakitan dan kematian. Risiko kematian lebih tinggi pada bayi dan anak yang menderita kekurangan gizi terutama apabila bayi dan anak juga menderita kekurangan gizi mikro. Penelitian di pengungsian menunjukkan bahwa kematian anak balita 2-3 kali lebih besar dibandingkan kematian pada semua kelompok umur. Kematian terbesar terjadi pada kelompok umur 0-6 bulan (WHOUNICEF, 2001). Oleh karena itu, penanganan gizi dalam situasi bencana menjadi bagian penting untuk menangani pengungsi secara cepat dan tepat (Kementerian Kesehatan RI, 2012).

Berdasarkan focus group discussion (FGD) yang dilakukan pada informan utama dalam penelitian ini, yaitu ibu yang memiliki balita yang pernah tinggal di posko pengungsian Desa Dasan Geria dan informan pendukung yaitu pihak stakeholder yang 
secara langsung terlibat dalam penanggulangan gizi balita (aparat Desa Dasan Geria, Puskesmas Sigerongan, BPBD Kabupaten Lombok Barat, Dinas Sosial Kabupaten Lombok Barat, dan Dinas Kesehatan Kabupaten Lombok Barat) maka diperoleh hasil penelitian sebagai berikut :

\section{KEGIATAN GIZI PRA BENCANA}

Kegiatan penanganan gizi pada pra bencana pada dasarnya merupakan kegiatan antisipasi terjadinya bencana dan mengurangi resiko dampak bencana. Kegiatan yang dilaksanakan antara lain sosialisasi dan pelatihan petugas seperti manajemen gizi bencana, penyusunan rencana kontijensi kegiatan gizi, konseling menyusui, konseling Makanan Pendamping Air Susu Ibu (MP-ASI), pengumpulan data awal daerah rentan bencana, penyediaan bufferstock MP-ASI, pembinaan teknis dan pendampingan kepada petugas terkait manajemen gizi bencana serta berbagai kegiatan terkait lainnya (Kementerian Kesehatan RI, 2012).

Hasil wawancara dengan para stakeholder sebagai berikut :

"Sebelum bencana terjadi belum ada pedoman atau SOP khusus untuk penanganan bencana" (S1)

"Selama ini, belum ada sosialisasi atau pelatihan petugas untuk mitigasi bencana; selain itu belum ada data awal wilayah yang rawan terkena gempa" (S2)

"Dinas Kesehatan memiliki Pedoman Asuhan Gizi untuk penanganan gizi balita pasca bencana" (S9)

Berdasarkan data di atas, hanya Dinas Kesehatan yang telah memiliki pedoman untuk penanganan gizi balita pasca bencana berupa Pedoman Kegiatan Gizi dalam Penanggulangan Bencana. Sementara stakeholder lainnya belum ada yang memiliki pedoman. Untuk rencana kontijensi (rencana kegiatan antisipasi bencana), belum ada stakeholder yang memiliki pedoman khusus untuk balita. Selain itu, belum ada data awal wilayah yang rawan terkena gempa, demikian juga sosialisasi dan pelatihan petugas untuk penanganan gizi dalam kondisi darurat belum pernah dilakukan.
Hal-hal di atas merupakan kendala dan tindakan yang perlu mendapat perhatian pada pra bencana. Menurut Haniarti dan Yusuf (2020), penanganan gizi balita pada kondisi bencana belum ditangani secara khusus. Perlu disusun SOP penanganan gizi balita pada kondisi pasca bencana dalam hal ini yang menjadi kewenangan Dinas Kesehatan sebagai pelaksana teknis. BPBD dan Dinas Sosial perlu menganggarkan dana untuk penyediaan makanan yang khusus untuk balita dan pengalokasian dana untuk pelatihan SDM untuk menangani gizi balita pada kondisi darurat bencana.

\section{KEGIATAN GIZI PADA SITUASI BENCANA (TANGGAP DARURAT AWAL DAN TANGGAP DARURAT LANJUT)}

Kegiatan penanganan gizi pada tahap tanggap darurat awal adalah kegiatan pemberian makanan agar pengungsi tidak lapar dan dapat mempertahankan status gizinya, sementara penanganan kegiatan gizi pada tahap tanggap darurat lanjut adalah untuk menanggulangi masalah gizi melalui intervensi sesuai masalah gizi yang ada.

Hasil FGD yang dilakukan dengan ibu yang memiliki balita dan pernah tinggal di pengungsian sebagai berikut :

"Selama di pengungsian yang memasak adalah ibu-ibu di pengungsian, tidak ada petugas khusus yang memasak dan menyiapkan makanan. Kami memasak di dapur umum, untuk 1 dapur umum rata-rata 3 tenda dengan kapasitas \pm 60 KK per tenda. Ada juga makanan siap santap yang diberikan oleh donatur"

"Makanan untuk balita tidak dipisahkan, digabung dengan makanan dewasa, yang membedakan tingkat kepedasan. Peralatan memasak untuk orang dewasa dan anak tidak dipisahkan"

"Dari puskesmas ada yang mengukur BB anak, kader juga keliling tenda-tenda pengungsian setiap bulan. Posyandu tetap dilaksanakan di tenda pengungsian. Saat bulan vitamin A (Agustus dan Februari) vitamin A diberikan oleh petugas puskesmas"

"Belum ada penyuluhan gizi khusus, yang ada trauma healing" 
Sementara itu, hasil wawancara dengan stakeholder sebagai berikut :

"Petugas khusus dapur umum di pengungsian adalah ibu-ibu sebagai juru masak. Mereka bergantian memasak untuk keperluan seluruh pengungsi. Makanan untuk balita belum dipisahkan dengan makanan untuk dewasa. Bantuan lebih banyak berupa makanan instan, sayur dan lauk pauk sangat kurang" (S1)

"Daftar menu dibuat siklus 7 hari, dapur umum salah satunya diinisiasi oleh organisasi Persagi (Persatuan Ahli Gizi) di kecamatan dan di provinsi, BPBD membuat dapur umum di kecamatan, ketersediaan makanan bergantung pada ketersediaan dana dari donatur. Jika dilihat dari AKG, bantuan makanan yang diberikan belum memenuhi kebutuhan gizi balita baik jumlah, kualitas maupun jenis makanan yang sesuai. Kebanyakan yang dikonsumsi adalah makanan instan. Tidak ada petugas gizi khusus di dapur umum pengungsian. Pendistribusian makanan berkoordinasi dengan BPBD dan Dinas Sosial. Kendala distribusi untuk menjangkau daerah terpencil dan tidak ada anggaran khusus yang dialokasikan untuk kebutuhan gizi balita, namun ada perubahan anggaran" (S9)

"Pengukuran antropometri tetap berjalan tiap bulan. Penyuluhan juga diberikan saat di pengungsian, yaitu penyuluhan Pemberian Makanan Pada Bayi dan Anak (PMBA)" (S10) "BPBD berperan dalam penanganan tanggap darurat, rehabilitasi dan rekonstruksi pasca bencana. Dibutuhkan koordinasi dengan instansi lain dalam menyusun langkah-langkah penanganan darurat bencana" (S6)

Berdasarkan hasil FGD dan wawancara kepada stakeholder dapat dilihat bahwa pada situasi bencana (tanggap darurat awal dan tanggap darurat lanjut) gempa bumi di Desa Dasan Geria beberapa hal yang menjadi catatan adalah sebagai berikut :

\section{a. Pengumpulan Data Antropometri Balita}

Dalam Pedoman Teknis

Penanggulangan Krisis Kesehatan Akibat Bencana (2007) disebutkan bahwa pemantauan pertumbuhan balita harus dilakukan setiap bulan menggunakan KMS, selanjutnya dilakukan penilaian keadaan gizi balita setelah 3 bulan untuk dibandingkan dengan data dasar
(Departemen Kesehatan RI, 2007). Hasil dari penelitian ini, pengumpulan data antropometri balita tetap dilakukan setiap bulan karena Posyandu tetap berjalan di lokasi pengungsian. Pengukuran antropometri dilakukan oleh kader Posyandu yang selanjutnya dilaporkan kepada bidan desa. Dengan adanya data antropometri balita, status gizi balita dapat tetap dipantau sehingga jika ada yang mengalami status gizi kurang dapat segera ditangani.

Hal yang menjadi kendala adalah terpencarnya titik-titik pengungsian dimana ada beberapa wilayah yang sulit terjangkau oleh alat transportasi akibat rusaknya jalan oleh gempa bumi maupun lokasinya yang sangat jauh dan terpencil sehingga data antropometri balita sulit didapatkan. Pihak desa selanjutnya berinisiatif untuk menugaskan beberapa petugas khusus untuk menjangkau wilayah-wilayah tersebut agar data sasaran dapat diperoleh.

Pada penelitian yang dilakukan oleh Nasrul dkk (2019) terhadap balita di pengungsian Kelurahan Buluri Kecamatan Ulujadi Kota Palu, terjadi kenaikan masalah gizi seperti naiknya angka gizi buruk dari sebelum bencana. Terjadinya pemicu kenaikan masalah gizi pasca bencana ditempat pengungsian karena kurangnya bahan makanan yang terjamin nilai gizinya, lingkungan tempat tinggal yang kurang bersih pasca bencana yang dapat menimbulkan penyakit, serta pola asuh dan kurangnya pendapatan orang tua yang mengakibatkan ekonomi kurang pasca bencana. Hal inilah yang mendasari pentingnya pengumpulan data antropometri balita pada situasi bencana.

\section{b. Ketersediaan Bahan Makanan Untuk Balita}

Berdasarkan hasil wawancara dan FGD didapatkan informasi bahwa baik dari segi jenis, kuantitas maupun kualitas ketersediaan makanan untuk balita belum memenuhi standar Angka Kecukupan Gizi (AKG). Tidak semua dapur umum membuat daftar menu makanan yang sesuai dengan standar ransum. Makanan balita dan dewasa tidak dipisahkan, hanya dibedakan 
dari tingkat kepedasan. Selain itu, balita lebih banyak mengkonsumsi makanan instan seperti seperti mie dan snack yang tentu saja kurang memenuhi zat gizi yang dibutuhkan oleh balita. Hal ini disebabkan oleh tidak adanya alokasi dana khusus yang disiapkan untuk pengadaan bahan makanan balita. Selain itu, tidak ada tenaga khusus yang menangani gizi balita. Masalah lainnya adalah sulitnya distribusi bantuan di beberapa wilayah yang sulit terjangkau akibat sarana dan prasarana yang rusak sehingga jenis dan jumlah bantuan tidak merata.

Tumenggung (2017) menyatakan bahwa salah satu dampak bencana terhadap menurunnya kualitas hidup penduduk dapat dilihat dari berbagai permasalahan kesehatan masyarakat yang terjadi. Bencana yang diikuti dengan pengungsian berpotensi menimbulkan masalah kesehatan. Persediaan pangan yang tidak mencukupi merupakan awal dari proses terjadinya penurunan derajat kesehatan yang dalam jangka panjang akan mempengaruhi secara langsung tingkat pemenuhan kebutuhan gizi korban bencana.

Hasil penelitian ini sejalan dengan penelitian yang dilakukan oleh Salmayati dkk. (2016), dimana penanganan gizi balita pada kondisi kedaruratan bencana banjir di Kecamatan Sampoiniet Kabupaten Aceh Jaya belum ditangani secara khusus dan tidak tersedianya makanan yang khusus untuk balita. Jumlah dan jenis makanan yang tersedia belum sesuai dan tidak dapat memenuhi kebutuhan gizi balita. Keterbatasan dana, sumber daya manusia serta cara pendistribusian dapat mempengaruhi ketersediaan bahan makanan untuk balita.

Penelitian yang dilakukan oleh Siagian, dkk. (2014) tentang penanganan gizi untuk balita di pengungsian erupsi Gunung Sinabung juga menyatakan bahwa penyajian menu makanan untuk anak balita bisa dikatakan minim, karena dapur umum tidak menyiapkan menu khusus untuk anak balita sehingga anak balita hanya mengkonsumsi makanan yang juga dikonsumsi orang dewasa. Padahal menu untuk orang dewasa didasari oleh ketersediaan bantuan yang diperoleh dari posko yang menyebabkan konsumsi makanan yang tidak beragam dan terbatas seperti kurangnya konsumsi ikan segar, buah, daging dan sebagainya yang merupakan sumber zat gizi guna pertumbuhan dan perkembangan balita.

Banyak kendala yang dialami selama penyelenggaraan makanan saat kondisi darurat bencana. Hal ini disebabkan pedoman bantuan pangan saat kondisi darurat bencana yang dikeluarkan oleh BNPB RI dan pedoman penanganan gizi dalam penanggulangan bencana yang dikeluarkan oleh Direktorat Jenderal Gizi dan Kesehatan Masyarakat Kemenkes RI belum sepenuhnya dipahami dan diimplementasikan secara teknis oleh masyarakat, terlebih dengan mempertimbangkan potensi lokal daerah bencana (Sumarto, dkk. 2019).

Masalah lain yang seringkali muncul adalah adanya bantuan pangan kemasan dari dalam dan luar daerah dengan masa kadaluwarsa yang sudah mendekati atau sudah lewat, makanan tidak disertai label yang jelas, tidak ada keterangan halal, serta melimpahnya bantuan susu formula bayi dan botol susu. Masalah tersebut diperburuk dengan kurangnya pengetahuan dalam penyiapan makanan pendamping air susu ibu (MP-ASI) atau makanan camilan untuk bayi dan anak berumur di atas 6 bulan, di bawah dua tahun (baduta) dan di bawah lima tahun (balita). Pemberian makanan yang tidak tepat pada kelompok tersebut dapat meningkatkan risiko kesakitan dan kematian (Kementerian Kesehatan RI, 2012).

Beberapa hal di atas menunjukkan bahwa tenaga kesehatan khususnya ahli gizi memiliki peranan penting dalam situasi bencana. Hasil kajian Widayatun dan Fatoni (2013) menyatakan bahwa partisipasi aktif masyarakat dan peran petugas kesehatan dalam penanganan korban pada saat terjadi bencana, masa tanggap darurat dan masa rehabilitasi memegang peranan penting 
dalam membantu masyarakat untuk bertahan hidup dan menjalani proses pemulihan dari dampak bencana.

Dalam penelitian ini diperoleh informasi bahwa PMT untuk balita disediakan oleh desa melalui anggaran dana desa dan diperoleh juga melalui Dinas Kesehatan. Selain itu, kapsul vitamin A tetap diberikan di lokasi pengungsian pada bulan vitamin A yaitu bulan Agustus dan Februari. Sementara itu, bantuan susu formula yang diterima berupa susu bubuk dan UHT yang berasal dari donatur.

\section{c. Penyuluhan Gizi}

Pada kondisi bencana gempa bumi di Desa Dasan Geria, Dinas Kesehatan melakukan penyuluhan Pemberian Makanan Bayi dan Anak (PMBA) pada beberapa titik pengungsian. Namun karena jumlah titik pengungsian yang sangat banyak dan terdapat beberapa lokasi yang sulit dijangkau oleh petugas maka penyuluhan tidak dapat dilakukan pada semua lokasi.

Penyuluhan gizi yang diberikan oleh tenaga petugas gizi pada kondisi darurat bencana mempunyai makna yang signifikan. Penyuluhan merupakan upaya perubahan perilaku manusia baik individu maupun masyarakat sehingga dapat menciptakan sikap mental dan kemampuan untuk memecahkan masalah yang dihadapinya guna dapat meningkatkan dan mempertahankan gizi yang baik (Salmayati, dkk. 2016). Menurut penelitian Zulaekah (2012), pendidikan atau penyuluhan gizi adalah pendekatan edukatif untuk menghasilkan perilaku individu atau masyarakat yang diperlukan dalam meningkatkan perbaikan pangan dan status gizi. Harapan dari upaya ini adalah orang bisa memahami pentingnya makanan dan gizi, sehingga mau bersikap dan bertindak mengikuti norma-norma gizi.

Salah satu harapan dari para ibu korban bencana gempa bumi ini adalah dipisahkannya tenda khusus untuk ibuibu terutama yang memiliki bayi dan balita agar lebih leluasa dalam mengasuh bayi dan balita terutama saat menyusui bayi mereka. Selain itu, dengan berada dalam satu tenda khusus para ibu dapat berbagi informasi mengenai cara perawatan maupun pengasuhan bayi dan balita. Dilain pihak, dengan dipisahkannya tenda khusus untuk ibuibu maka kegiatan penyuluhan dapat lebih efektif dan efisien.

\section{KEGIATAN GIZI PASCA BENCANA}

Penanganan gizi pasca bencana pada dasarnya adalah melaksanakan pemantauan dan evaluasi sebagai bagian dari surveilans, untuk mengetahui kebutuhan yang diperlukan (need assessment) dan melaksanakan kegiatan pembinaan gizi sebagai tindak lanjut atau respon dari informasi yang diperoleh secara terintegrasi dengan kegiatan pelayanan kesehatan masyarakat (public health response) untuk meningkatkan dan mempertahankan status gizi dan kesehatan korban bencana.

Dari hasil wawancara diperoleh informasi bahwa beberapa kendala yang dihadapi di lokasi pengungsian telah dicatat untuk dilakukan pemantauan dan evaluasi. Beberapa kendala yang dihadapi diantaranya sulitnya pengumpulan data bayi dan balita karena lokasi pengungsian yang tersebar di banyak titik; sulitnya distribusi bantuan untuk daerah terpencil, selain karena lokasinya yang sulit dijangkau juga karena keterbatasan petugas distribusi, kurangnya alat transportasi dan rusaknya sarana prasarana akibat gempa yang terjadi. Kendala lainnya adalah tidak memadainya ketersediaan makanan untuk balita baik dari segi jenis, kuantitas maupun kualitas serta terbatasnya tenaga khusus yang menangani gizi balita saat bencana. Selain itu, tidak adanya anggaran khusus yang dialokasikan untuk kebutuhan gizi balita menjadi catatan penting.

Dalam SK Menkes Nomor 1357 Tahun 2001 mengenai Standar Minimal Penanggulangan Masalah Kesehatan Akibat Bencana dan Penanganan Pengungsi disebutkan bahwa penanggulangan masalah gizi di pengungsian diantaranya adalah melaksanakan profesionalisme tenaga lapangan untuk penanganan gizi pengungsi melalui orientasi dan pelatihan; melakukan surveilans gizi untuk memantau 
perkembangan jumlah pengungsi, status gizi dan kesehatan; meningkatkan kooordinasi lintas program, lintas sektoral, LSM dan ormas dalam penanggulangan masalah gizi dalam setiap tahap; serta pemberdayaan pengungsi di bidang pemenuhan kebutuhan pangan yang dilakukan sejak awal pengungsian (Pusat Penanggulangan Masalah Kesehatan Sekjen Depkes RI, 2001).

Beberapa pengalaman keberhasilan pelaksanaan kegiatan gizi untuk balita dalam kejadian bencana dapat dijadikan pelajaran. Salah satunya adalah dalam penanggulangan bencana Sinabung tahun 2010-2014, dimana sejak pra bencana, saat kondisi bencana dan pasca bencana telah dilaksanakan beberapa kegiatan gizi diantaranya sosialisasi penanganan gizi bencana, pengumpulan data antropometri balita, konseling menyusui/MPASI, pengawasan susu formula dan distribusi biskuit MP-ASI (Pusat Krisis Kesehatan Kemenkes RI, 2015).

\section{KESIMPULAN}

1. Kegiatan gizi pra bencana belum terlaksana dengan baik karena belum adanya data awal wilayah yang rawan terkena gempa serta belum terlaksananya sosialisasi dan pelatihan petugas untuk penanganan gizi balita.

2. Pada situasi bencana, pengumpulan data antropometri balita tetap dilakukan setiap bulan; namun untuk penyuluhan gizi belum dapat dilaksanakan di setiap titik pengungsian karena terkendala sarana dan prasarana yang kurang memadai. Demikian pula dengan ketersediaan makanan untuk balita baik dari segi jenis, kuantitas maupun kualitas belum memenuhi standar Angka Kecukupan Gizi yang dianjurkan.

3. Kegiatan gizi pasca bencana berupa pemantauan dan evaluasi telah dilaksanakan dengan tujuan untuk meningkatkan dan mempertahankan status gizi dan kesehatan balita korban bencana.

\section{SARAN}

1. Perlu disusun pedoman dan anggaran khusus untuk penanganan gizi balita dalam kondisi kedaruratan.

2. Kerjasama lintas sektor dan lintas program harus dimaksimalkan agar penanganan gizi balita saat kondisi bencana dapat dioptimalkan.

\section{UCAPAN TERIMA KASIH}

Peneliti mengucapkan terima kasih yang sebesar-besarnya kepada Direktorat Riset dan Pengabdian Masyarakat (DRPM) Deputi Bidang Penguatan Riset dan Pengembangan, Kementerian Riset dan Teknologi/Badan Riset dan Inovasi Nasional sebagai penyandang dana penelitian pada skema Penelitian Dosen Pemula (PDP) Tahun 2020 dan kepada LP2M Universitas Nahdlatul Ulama Nusa Tenggara Barat yang telah ikut memfasilitasi kelancaran proses penelitian ini.

\section{DAFTAR PUSTAKA}

Departemen Kesehatan RI. 2007. Pedoman Teknis Penanggulangan Krisis Kesehatan Akibat Bencana. Jakarta.

Haniarti, Yusuf S. 2020. Manajemen Penanganan Gizi Balita Pasca Bencana. Jurnal Ilmiah Manusia dan Kesehatan 1(1): 133-142.

Kementerian Kesehatan RI. 2012. Pedoman Kegiatan Gizi dalam Penanggulangan Bencana. Jakarta.

Milles dan Hubberman, 1992. Analisis Data Kualitatif. Jakarta : Gramedia.

Nasrul, Candriasih P, Arifin, NA. 2019. Status Gizi Anak Balita Pasca Bencana di Pengungsian Kelurahan Buluri Kota Palu Provinsi Sulawesi Tengah. Gizido 11(2) : 71-80.

Oktari, RS, 2019. Peningkatan Kapasitas Desa Tangguh Bencana. Jurnal Pengabdian kepada Masyarakat (Indonesian Journal of Community Engagement), 4(2), pp. 189197.

Pusat Krisis Kesehatan Kemenkes RI. 2015. Modul Peningkatan Kapasitas Petugas Kesehatan dalam Pengurangan Resiko 
Bencana Internasional. Jakarta.

Pusat Penanggulangan Masalah Kesehatan

Sekjen Depkes RI. 2001. Keputusan Menteri Kesehatan RI No : 1357/Menkes/SK/XII/2001 tentang Standar Minimal Penanggulangan Masalah Kesehatan Akibat Bencana dan Penanganan Pengungsi. Jakarta.

Raco, JR, 2010. Metode Penelitian Kualitatif Jenis, Karakteristik dan Keunggulannya. Jakarta : Gramedia.

Salmayati, Hermansyah, Agussabti. 2016. Kajian Penanganan Gizi Balita Pada Kondisi Kedaruratan Bencana Banjir di Kecamatan Sampoiniet Kabupaten Aceh Jaya. Jurnal Kedokteran Syiah Kuala 16(3): 176-180.

Siagian, dkk. 2014. Gambaran Status Gizi dan Penyakit Infeksi Pada Anak Balita (12-59 bulan) di Posko Pengungsian Erupsi Gunung Sinabung Kabupaten Karo tahun 2014. Universitas Sumatra Utara; 2014.

Sinaga, NS, 2015. Peran Petugas Kesehatan Dalam Manajamen Penanganan Bencana Alam. Jurnal Ilmiah Integritas 1(1) :1-7.

Sumarto, Radiati A, Listianasari Y. 2019. Peningkatan Kapasitas Tenaga Penyelenggara Makanan Darurat Bencana melalui Penyuluhan di Desa Sukarasa, Salawu, Tasikmalaya. Agrokreatif Jurnal Ilmiah Pengabdian kepada Masyarakat 5(3): 266-274.

Tumenggung I. 2017. Masalah Gizi dan Penyakit Menular Pasca Bencana. Health and Nutrition Journal III(1):1-9.

Widayatun, Fatoni Z. 2013. Permasalahan Kesehatan dalam Kondisi Bencana : Peran Petugas Kesehatan dan Partisipasi Masyarakat. Jurnal Kependudukan Indonesia, 8(1) : 37-52.

Zulaekah S. Pendidikan Gizi Dengan Media
Booklet Terhadap Pengetahuan Gizi. Jurnal Kesehatan Masyarakat; 2012 : 7 (2) 127-133. 